\title{
Species distinction of the ascomycetous heterothallic yeast-like fungus Stephanoascus ciferrii complex: description of Candida allociferrii sp. nov. and reinstatement of Candida mucifera Kocková-Kratochvílová et Sláviková
}

Institute for Fermentation, Osaka (IFO) 17-85, Jusohonmachi 2-chome, Yodogawa-ku, Osaka 532-8686, Japan
Kumiko Ueda-Nishimura and Kozaburo Mikata Author for correspondence: Kumiko Ueda-Nishimura. Tel: +8166300 6555. Fax: +81663006814.
e-mail: nishimura-kumiko@ifo.or.jp
Keywords: Stephanoascus ciferrii, Candida allociferrii sp. nov., rDNA sequences, group I intron, DNA-DNA hybridization

\section{INTRODUCTION}

The definition of a species, whether of higher plants, animals or micro-organisms, is based on the principle of genetic isolation. Members of a species are considered interfertile, whereas genetically separate species are not (Dobzhansky, 1976). However, this definition

The DDBJ accession numbers for the sequences reported in this paper are $A B 000658-A B 000662, A B 019362$ and AB041003-AB041006. is unsuitable for homothallic or anamorphic (asexual) yeasts. Therefore, until the late $1960 \mathrm{~s}$, the primary means for defining species of yeasts lay in the subjective appraisal and weighting of phenotypic properties. Nevertheless, the use of growth reactions could result in the erroneous definition of a species, since the assimilation and fermentation of many compounds are controlled by one or only a few genes (Lindegren \& Lindegren, 1949; Winge \& Roberts, 1949). At present, measurements of DNA reassociation are used to define yeast species on the basis of overall genetic 
similarity (Kurtzman, 1987; Kurtzman \& Phaff, 1987). Furthermore, rRNA gene (rDNA) sequences are used to measure evolutionary relationships and are studied with the aim of rapid yeast identification (Kurtzman \& Robnett, 1998).

In this study we found that some strains of Stephanoascus ciferrii had $18 \mathrm{~S}$ rDNA containing group I introns. Group I introns are a class of mobile genetic elements defined in part by the possession of a set of conserved $\mathrm{P}, \mathrm{Q}, \mathrm{R}$ and $\mathrm{S}$ sequences (Davies et al., 1982), and they exist in many eukaryotes (Cech, 1988; Sogin \& Edman, 1989), prokaryotes (Kuhsel et al., 1990; Reinhold-Hurek \& Shub, 1992; Xu et al., 1990) and viruses (Shub et al., 1988; Yamada et al., 1994). They have frequently been found in fungal $18 \mathrm{~S}$ rDNA (De Wachter et al., 1992; Hibbett, 1996; Gargas et al., 1995; Nishida \& Sugiyama, 1995; Takashima et al., 1996; Ueda \& Mikata, 1999). It has been reported that introns can be transmitted vertically among lineages as well as horizontally (Hibbett, 1996; Bhattacharya et al., 1996).

Smith \& de Hoog (1998) reported that the heterothallic ascomycetous yeast-like fungus Stephanoascus ciferrii Smith et al. (1976) included three synonyms, Candida ciferrii Kreger-van Rij (1965), Sporothrix catenata de Hoog \& Constantinescu (1981) and Candida mucifera Kocková-Kratochvílová \& Sláviková (1988). In this paper we report on the DNA similarity, mating, $18 \mathrm{~S}$ rDNA and 26S rDNA domain D1/D2 sequences of nine strains of the Stephanoascus ciferrii complex and discuss their species distinctions.

\section{METHODS}

DNA preparation and DNA-DNA hybridization. Yeast strains are listed in Table 1 . The strains were cultured at $28^{\circ} \mathrm{C}$ with shaking for 10-24 h in $200 \mathrm{ml}$ Erlenmeyer flasks containing $50 \mathrm{ml}$ YPD broth. For protoplast preparation and DNA extraction the protocol of Holm et al. (1986) was followed, as modified by Kaneko \& Banno (1991). DNA-DNA homology between strains was studied by the photobiotin microplate hybridization method of Ezaki et al. (1988, 1989), as modified by Kaneko \& Banno (1991). Calculations were based on the means of five measurements.

$18 \mathrm{~S}$ rDNA sequencing. 18S rRNA gene (rDNA) sequences were determined using a Thermo Sequenase Fluorescent Labelled Primer Cycle Sequencing Kit with 7-deaza-dGTP (Amersham Pharmacia Biotech), following the supplier's protocol. PCR for amplification of $18 \mathrm{~S}$ rDNA and cycle sequencing using PCR products were performed as described by Ueda-Nishimura \& Mikata (1999). In addition to some primers described in Ueda-Nishimura \& Mikata (1999), the following 5' FITC-labelled primers were also used for sequencing: 1600F (5'-TTGTACACACCGCCCGTCGC$\left.3^{\prime}\right)$ for the sense strand and 1627R (5'-TAGCGACGGGCGGTGTGTAC-3') for the reverse strand.

Similarity searches and secondary structure modelling of group I introns. A BLAST search (Altschul et al., 1990) was conducted using DDBJ, GenBank and EMBL databases. Intron secondary structure was drawn following the model of Cech et al. (1994). GENETYX-MAC version 8 (Software Development) was used to help predict stem structures in the less conserved portions of the model.

265 rDNA domain D1/D2 sequencing. The $600 \mathrm{nt}$ 26S rDNA domain D1/D2 sequences were determined by using a BigDye Terminator Cycle Sequencing FS Ready Reaction Kit (PE Biosystems), CentriSep spin column (PE Biosystems) and an ABI PRISM 310 Genetic Analyzer (PE Biosystems), following the manufacturers' protocols. For amplification of 26S rDNA domain D1/D2 sequences, PCR (Saiki et al., 1988) was performed for 30 cycles of denaturation at $94{ }^{\circ} \mathrm{C}$ for $30 \mathrm{~s}$, annealing at $57^{\circ} \mathrm{C}$ for $30 \mathrm{~s}$ and extension at $72^{\circ} \mathrm{C}$ for $45 \mathrm{~s}$ with TaKaRa Taq DNA polymerase (Takara), using the primer pair NL-1 (5'-GCATATCAATAAGCGGAGGAAAAG-3') and NL-4 (5'-GGTCCGTGTTTCAAGACGG-3') (Kurtzman \& Robnett, 1997). The PCR products were purified with GFX PCR DNA and the Gel Band Purification Kit (Amersham Pharmacia Biotech), following the supplier's protocol. For sequencing, purified

Table 1. Stephanoascus ciferrii complex strains

\begin{tabular}{|c|c|c|c|c|c|}
\hline & \multicolumn{3}{|c|}{ Strain } & \multirow[t]{2}{*}{ Mating type* } & \multirow[t]{2}{*}{ Other information } \\
\hline & IFO & CBS & JCM & & \\
\hline \multicolumn{6}{|l|}{ Group A } \\
\hline & 10193 & 5165 & & $\alpha$ & \\
\hline & $10194^{\mathrm{T}}$ & $5166^{\mathrm{T}}$ & & $\alpha$ & \\
\hline & 10913 & & 2984 & - & \\
\hline \multicolumn{6}{|l|}{ Group B } \\
\hline & $1854^{\mathrm{IT}}$ & $5295^{\mathrm{IT}}$ & $7621^{\mathrm{IT}}$ & $\alpha$ & Isotype strain of Stephanoascus ciferrii \\
\hline & $1855^{\mathrm{IT}}$ & $6699^{\mathrm{IT}}$ & $7622^{\mathrm{IT}}$ & a & Isotype strain of Stephanoascus ciferrii \\
\hline & $10192^{\mathrm{T}}$ & $4856^{\mathrm{T}}$ & $9551^{\mathrm{T}}$ & $\alpha$ & Type strain of Candida ciferrii \\
\hline & 10195 & 5646 & & a & \\
\hline & $32952^{\mathrm{T}}$ & $215 \cdot 79^{\mathrm{T}}$ & $2921^{\mathrm{T}}$ & - & Type strain of Sporothrix catenata \\
\hline \multicolumn{6}{|l|}{ Group C } \\
\hline & $10918^{\mathrm{T}}$ & $7409^{\mathrm{T}}$ & & a & Type strain of Candida mucifera \\
\hline
\end{tabular}

* Data from Smith \& de Hoog (1998). 
PCR products were used as a template, and NL-1 and NL-4 were used as primers.

Phylogenetic analysis. Sequence data were manually aligned with rDNA sequences of representative related species obtained from DDBJ and GenBank. Positions that could not be compared among all sequences, corresponding to indels and regions difficult to align between strains, were omitted from the phylogenetic analysis. A phylogenetic tree was constructed by Kimura's two-parameter method (Kimura, 1980) and the neighbour-joining method (Saitou \& Nei, 1987) using CLUSTAL W. Bootstrap values (Felsenstein, 1985) were calculated from 1000 replicates.

Assimilation and mating test. Physiological, morphological and cultural characteristics and mating types were investigated according to Yarrow (1998). Corn meal agar Dalmau plates were used as sporulation medium.

Ascospore germination. Single spores isolated by a manipulator were cultured on YM agar at $24^{\circ} \mathrm{C}$ for 1 week.

\section{RESULTS AND DISCUSSION}

\section{Sequencing of 185 rDNA and prediction of group I intron secondary structures}

Strains of the Stephanoascus ciferrii complex studied and their mating types reported by Smith \& de Hoog (1998) are listed in Table 1. 18S rDNA sequences of the nine strains were determined by the direct method. Insertion sequences were found in the $18 \mathrm{~S}$ rDNA sequences of six strains. The nine strains were separated by $18 \mathrm{~S}$ rDNA sequences into three groups: group A strains have no insertion in their $18 \mathrm{~S}$ rDNA, group B strains have an insertion sequence of 404 bases (Sc1506-1) at position 1506 and the group C strain has insertion sequences of 355 and 403 bases (Sc943 and Sc1506-2) at positions 943 and 1506, respectively (nucleotide positions according to Gutell, 1993) (Fig. 1). Sc1506-1 and Sc1506-2 at position 1506 were very similar, but not identical. Group A consists of three strains with identical sequences. Group B consists of five strains, including the isotype strains of Stephanoascus ciferrii (IFO $1854^{\mathrm{IT}}$ and IFO $1855^{\mathrm{IT}}$ ) and the type strains of Candida ciferrii (IFO $10192^{\mathrm{T}}$ ) and Sporothrix catenata (IFO $32952^{\mathrm{T}}$ ), and again all have identical sequences. Group $\mathrm{C}$ consists of a single

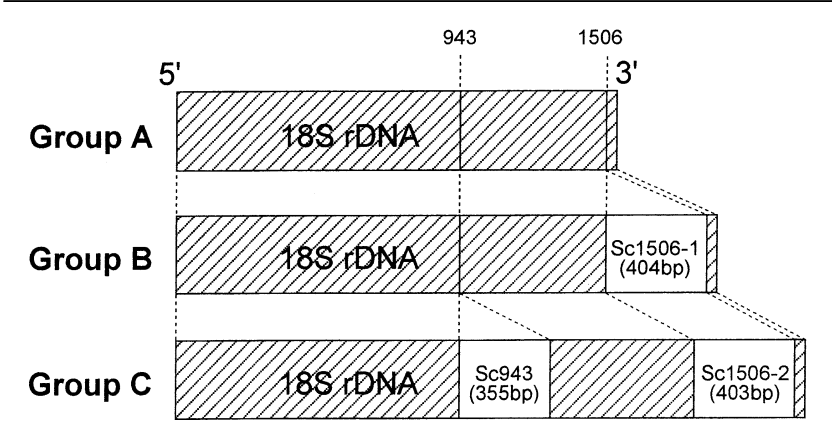

Fig. 1. 18S rDNA primary structures of the Stephanoascus ciferrii complex. Shaded boxes indicate $18 \mathrm{~S}$ rRNA coding regions; white boxes indicate insertion sequences. member, the type strain of Candida mucifera (IFO $10918^{\mathrm{T}}$ ) (Table 1).

The BLAST search revealed that the three insertion sequences, Sc1506-1, Sc1506-2 and Sc943, are similar to the sequences of many group I introns, and they are therefore thought also to be group I introns. The conserved $\mathrm{P}, \mathrm{Q}, \mathrm{R}$ and $\mathrm{S}$ regions of group I introns were found by the BLAST search. The catalytic core sequences corresponding to $\mathrm{P}, \mathrm{Q}, \mathrm{R}$ and $\mathrm{S}$ interact to form stems $\mathrm{P} 4$ and $\mathrm{P} 7$, which are parts of the conserved secondary structure core of group I introns (Cech, 1988). The catalytic core sequences of Sc1506-1 and Sc1506-2 were identical to that of one of the Tilletiopsis flava group I introns (GenBank accession numbers D82819 and X13687), while that of Sc943 differed from those of all known introns. The internal guide sequences (IGSs) located just downstream of the $5^{\prime}$ splice site and in the upstream part of the $5^{\prime}$ splice site interact to form stem P1. Using these sequences and structures (Sogin \& Edman, 1989; Wilcox et al., 1992; De Wachter et al., 1992) as guides, the remaining parts of the sequence could be folded to fit the secondary structure model of Cech et al. (1994) for group I introns. The complexes P1, P5 and P9 were predicted by use of the RNA secondary structure prediction program in the GENETYX software package. The predicted secondary structures of group I introns Sc15061, Sc1506-2 and Sc943 (data not shown) corresponded to subgroup IC1, listed by Michel \& Westhof (1990).

In comparison with Sc1506-1, Sc1506-2 has 4 base substitutions, 7 base insertions and 8 base deletions. This closely homologous relation between Sc1506-1 and Sc1506-2 suggests that these introns existed in the common ancestor of groups $\mathrm{B}$ and $\mathrm{C}$, and that they were vertically inherited. The substitution rate between the two introns was $1.0 \%(=4$ substitutions per 396 bases compared). On the other hand, that between $18 \mathrm{~S}$ rDNA exons of groups B and C was $0.46 \%$ (= 8 substitutions per 1754 bases compared). Our observations suggest that group I intron sequences evolve approximately $2 \cdot 2$ times more rapidly than $18 \mathrm{~S}$ rDNA exon sequences.

\section{DNA-DNA hybridization}

DNA-DNA hybridization was tested with DNAs from the nine strains and photobiotin-labelled DNA from IFO 10193 (group A), IFO $1854^{\mathrm{IT}}$ and IFO $32952^{\mathrm{T}}$ (group B) and IFO $10918^{\mathrm{T}}$ (group C). The results are shown in Table 2. DNA similarity values among group A strains were $86-100 \%$, and those among group B strains were $79-100 \%$. These data showed that group A strains and group B strains should each be considered to be conspecific. Groups A and B showed intermediate similarity values (41$66 \%$ ), suggesting that they represent different, but closely related species. IFO $10918^{\mathrm{T}}$ (group C) showed low similarity $(10-41 \%)$ to all of the tested strains. Thus, it is suggested that IFO $10918^{\mathrm{T}}$ (group C) is independent of groups A and B. 
Table 2. DNA similarity

Hybridization was performed at $45^{\circ} \mathrm{C}$. Boldface type indicates intra-group values; ND, not determined.

\begin{tabular}{|c|c|c|c|c|}
\hline \multirow[t]{3}{*}{ Strain } & \multicolumn{4}{|c|}{ DNA similarity ( \%) } \\
\hline & \multirow{2}{*}{$\begin{array}{c}\text { Group A } \\
\text { IFO } 10193\end{array}$} & \multicolumn{2}{|c|}{ Group B } & \multirow{2}{*}{$\begin{array}{c}\text { Group C } \\
\text { IFO 10918 }\end{array}$} \\
\hline & & IFO $1854^{\mathrm{IT}}$ & IFO $32952^{\mathrm{T}}$ & \\
\hline \multicolumn{5}{|l|}{ Group A } \\
\hline IFO 10193 & 100 & 63 & 47 & 29 \\
\hline IFO $10194^{\mathrm{T}}$ & 86 & 41 & 48 & 12 \\
\hline IFO 10913 & 96 & 66 & 65 & 33 \\
\hline \multicolumn{5}{|l|}{ Group B } \\
\hline IFO $1854^{\mathrm{IT}}$ & 52 & 100 & 88 & 15 \\
\hline IFO $1855^{\mathrm{IT}}$ & 46 & 94 & 79 & 11 \\
\hline IFO $10192^{\mathrm{T}}$ & 50 & 100 & 98 & 14 \\
\hline IFO 10195 & 42 & 92 & 81 & 10 \\
\hline IFO $32952^{\mathrm{T}}$ & ND & ND & 100 & ND \\
\hline \multicolumn{5}{|l|}{ Group C } \\
\hline IFO $10918^{\mathrm{T}}$ & 41 & 33 & 27 & 100 \\
\hline \multicolumn{5}{|l|}{ Saccharomyces cerevisiae } \\
\hline IFO 10217 & $5 \cdot 5$ & $7 \cdot 1$ & ND & $1 \cdot 4$ \\
\hline
\end{tabular}

Table 3. Mating test

IFO 10193 and IFO 10913 of group A did not mate with any of the tested strains. i, Ascospores immature; +a, ascus formed, but not ascospores.

\begin{tabular}{|c|c|c|c|c|}
\hline \multirow[t]{2}{*}{ Strain } & \multirow[t]{2}{*}{ Mating type* } & \multirow{2}{*}{$\frac{\text { Group A }}{\text { IFO 10194 } \alpha}$} & \multicolumn{2}{|c|}{ Group B } \\
\hline & & & IFO $1854^{I T} \alpha$ & IFO $10192^{\mathrm{T}} \alpha$ \\
\hline \multicolumn{5}{|l|}{ Group B } \\
\hline IFO $1855^{\text {IT }}$ & $\mathrm{a}$ & $+\mathrm{i}$ & +++ & + \\
\hline IFO 10195 & $\mathrm{a}$ & $+\mathrm{i}$ & + & + \\
\hline Group C & & & & \\
\hline IFO $10918^{\mathrm{T}}$ & $\mathrm{a}$ & $+\mathrm{a}$ & $+\mathrm{i}$ & $+\mathrm{i}$ \\
\hline
\end{tabular}

* Data from Smith \& de Hoog (1998).

\section{Mating tests}

Mating abilities between strains were tested and the results are shown in Table 3 . The combination of group B strains caused sporulation, with the combination of the isotype strains of Stephanoascus ciferrii (IFO $1854^{\mathrm{IT}}$ and IFO $1855^{\mathrm{IT}}$ ) causing especially frequent sporulation (Fig. 2a). The combination of groups $\mathrm{B}$ and $\mathrm{A}$ and of groups $\mathrm{B}$ and $\mathrm{C}$ also caused sporulation, but ascospores did not mature (Fig. 2b, c). The combination of groups $\mathrm{A}$ and $\mathrm{C}$ formed asci, but not ascospores. IFO 10193 and IFO 10913 of group A did not mate with any of the tested strains. IFO 10193 (= CBS 5165), which has been shown to be mating type $\alpha$ (Smith \& de Hoog, 1998), might have lost mating ability. The fact that all groups could mate with each other indicated that the three groups are closely related.

The ascospores formed between group B strains could not germinate. The reasons for this finding are not clear, but it is possible that the conditions for maturation or germination of ascospores were inadequate, or that the abilities of maturation or germination were lost. Whatever the reason, the species of tested strains could not be defined by their interfertility in the mating test. Therefore, we attempted to estimate interfertility on the basis of intron composition. In the anamorphic yeast Candida albicans and the yeast-like fungus Pneumocystis carinii, the group I intron composition of $25 \mathrm{~S}$ or $16 \mathrm{~S}$ rDNA has been reported to be variable among strains (McCullough et al., 1999; Liu \& 

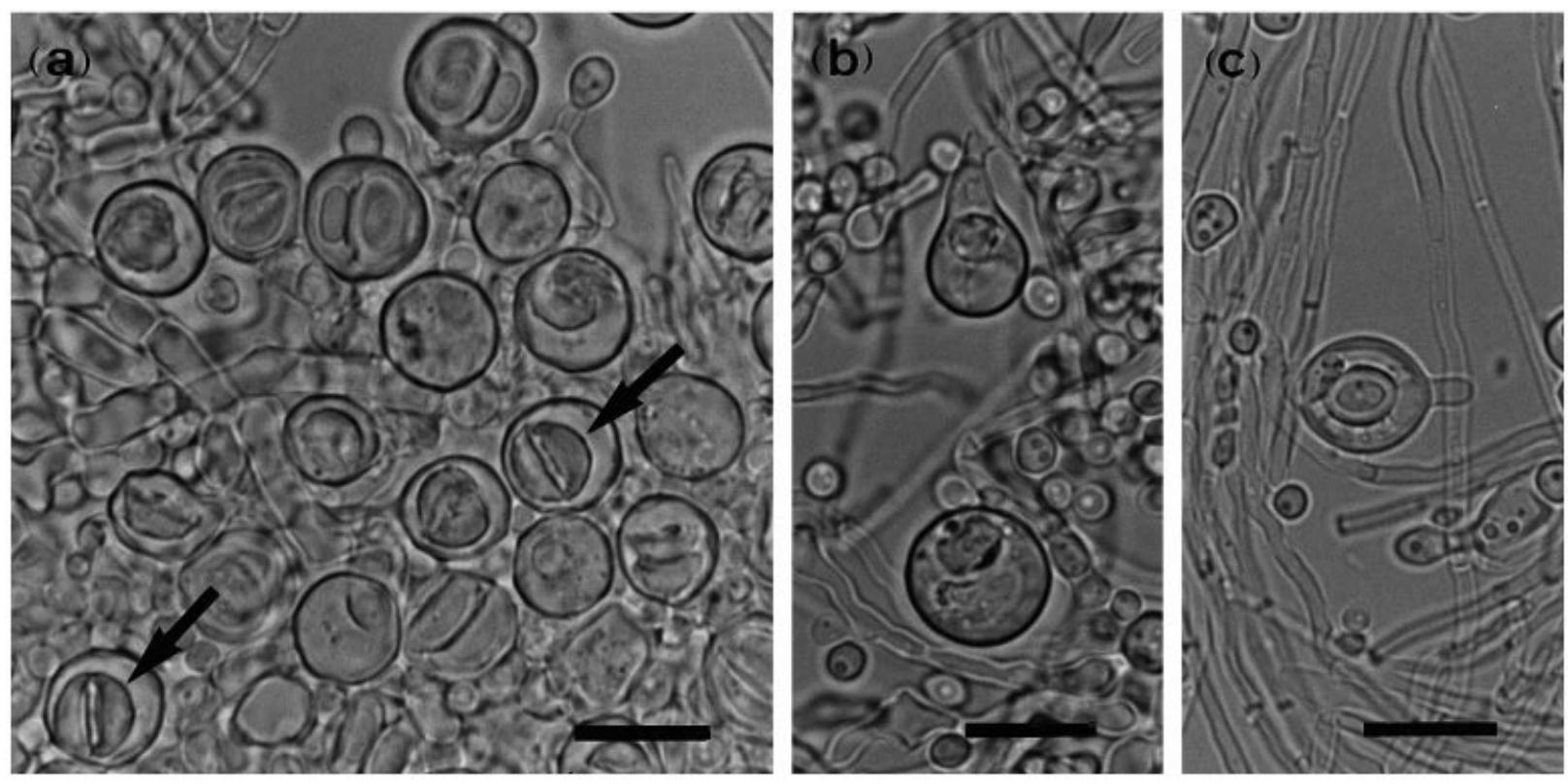

Fig. 2. Photomicrographs of asci on corn meal agar. (a) IFO $1854^{I T} \alpha \times$ IFO $1855^{I T}$ a, (b) IFO $10194^{\top} \alpha \times$ IFO 10195 a, (c) IFO $10192^{\top} \alpha \times$ IFO $10918^{\top}$ a. Arrows show mature ascospores. Bars, $5 \mu \mathrm{m}$.

Table 4. Distinguishing characteristics of clusters

$+\mathrm{s}$, Slow growth; +w, weak growth.

\begin{tabular}{|lccc|}
\hline Characteristic & Group A & Group B & Group C \\
\hline Assimilation of: & & & \\
Melibiose & $+\mathrm{w} /+$ & $+\mathrm{w}$ & - \\
Inulin & $+\mathrm{w}$ & - & - \\
Growth at: & & & \\
$35^{\circ} \mathrm{C}$ & + & + & $+\mathrm{s}$ \\
$37^{\circ} \mathrm{C}$ & + & + & - \\
\hline
\end{tabular}

Leibowitz, 1993), while in the Stephanoascus ciferrii complex, the intron composition of $18 \mathrm{~S}$ rDNA was uniform within strains of the same group. This indicates that intron composition spread by sexual reproduction and became fixed in each group. Therefore, although sexual reproduction between group A strains was not observed (Table 3), it is expected that new strains of group A will be isolated and that sexual reproduction between group A strains will be observed.

\section{Physiological and cultural characters}

In their physiological characters, all tested strains were similar to each other. Properties usable for discrimination of the groups are presented in Table 4. Group A strains differed from group B and C strains in their ability to assimilate inulin. The group $\mathrm{C}$ strain differed from strains in groups A and B by lack of growth at $37^{\circ} \mathrm{C}$. Physiological characters of group B were intermediate between those of groups $\mathrm{A}$ and $\mathrm{C}$.

\section{Phylogeny}

18S rDNA sequences of the related species (Yamada \& Nogawa, 1990) were determined by the direct method and that of Arxula terrestris was obtained from DDBJ (Fig. 3a). No group I introns were found in 18S rDNA sequences of related species, except for that at position 1199 in Arxula terrestris (Ueda \& Mikata, 1999). Fig. 3(a) shows a phylogenetic tree calculated from $18 \mathrm{~S}$ rDNA exon sequences of groups $\mathrm{A}, \mathrm{B}$ and $\mathrm{C}$, and related species. It is shown that group $\mathrm{C}$ diverged first from the ancestor of the Stephanoascus ciferrii complex and that groups A and B are close relatives with 1 base substitution.

In general, the number of base substitutions of $26 \mathrm{~S}$ rDNA domain D1/D2 sequences is much higher than that of $18 \mathrm{~S}$ rDNA exon sequences, and the $26 \mathrm{~S}$ rDNA domain D1/D2 sequences therefore provide a somewhat higher resolution of terminal lineages than do the $18 \mathrm{~S}$ rDNA exon sequences. Since no differences within the same group were found in the $18 \mathrm{~S}$ rDNA sequences, the 26S rDNA domain D1/D2 sequences of the Stephanoascus ciferrii complex were determined to investigate the diversity within each group. The intraspecific variation in $26 \mathrm{~S}$ rDNA domain D1/D2 sequences is reported to be up to $3 \mathrm{nt}$ differences, except for contiguous indels (Kurtzman \& Robnett, 1998). Sequences were found to be identical within the same group, except that IFO $10192^{\mathrm{T}}$ of group B has 1 base insertion compared with other strains of group B. Despite this exception, groups A and B were each considered to be a genetically homogeneous population. Fig. 3(b) shows a phylogenetic tree calculated from 26S rDNA domain D1/D2 sequences of Stephanoascus ciferrii groups $\mathrm{A}, \mathrm{B}$ and $\mathrm{C}$, and related species 


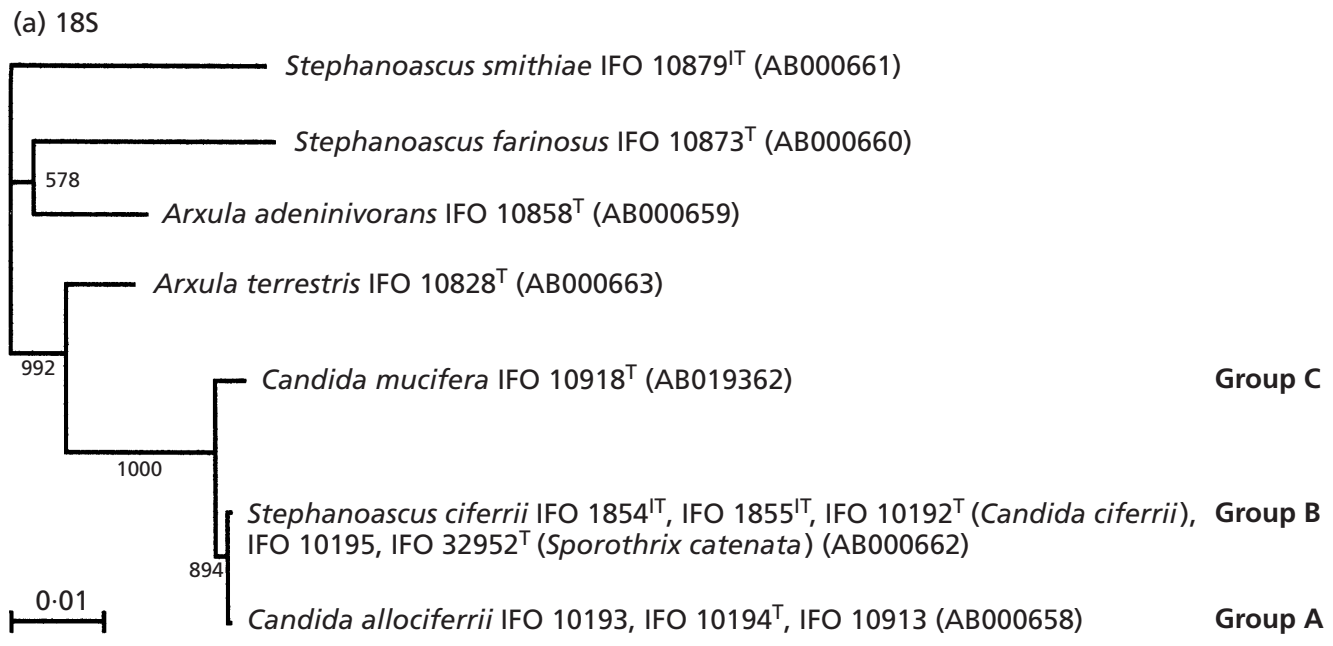

(b) $26 \mathrm{~S} \mathrm{D1/D2}$

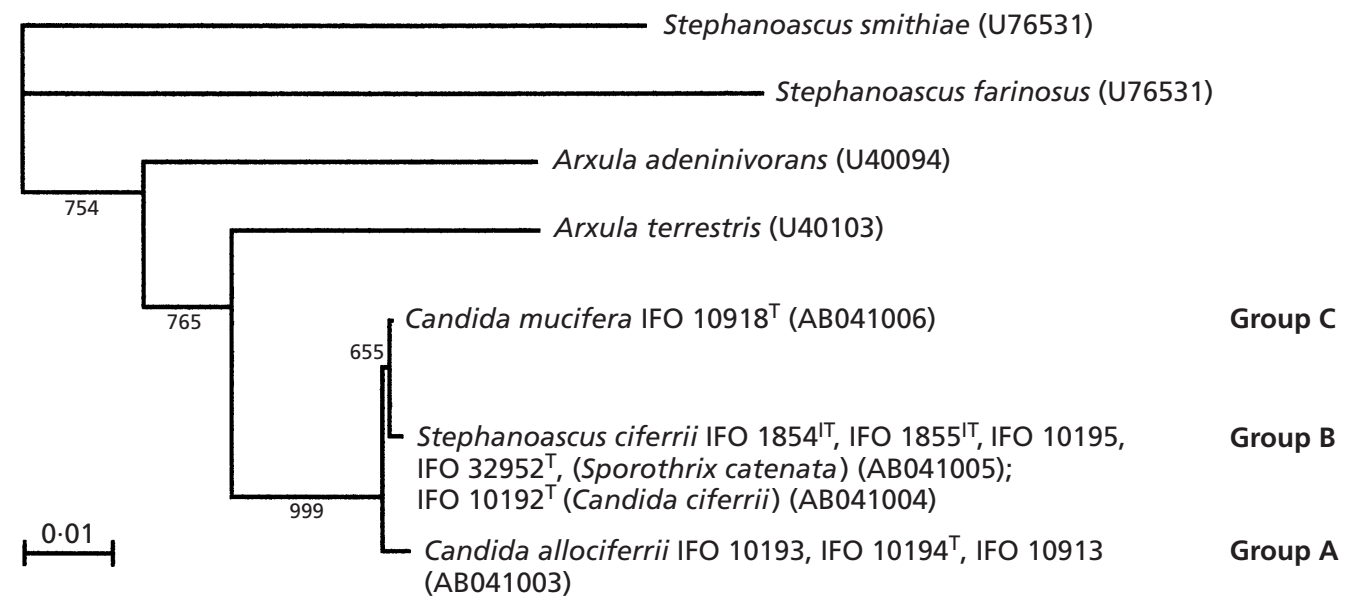

Fig. 3. Phylogenetic trees calculated by neighbour-joining, depicting relationships among the Stephanoascus ciferrii complex and related species analysed by $18 \mathrm{~S}$ rDNA (a) and 26S rDNA domain D1/D2 (b) sequences. Bootstrap values were calculated from 1000 trees. DDBJ accession numbers are shown in parentheses. Bar, sequence dissimilarity value of $1 \%$.

obtained from GenBank, EMBL and DDBJ. The three groups were found to be close relatives within 5 base substitutions.

Comparison of the 26S rDNA domain D1/D2 sequences revealed only 1 base substitution between groups $\mathrm{B}$ and $\mathrm{C}$, indicating that they were the closest relatives (Fig. 3b). This was not consistent with the phylogeny of $18 \mathrm{~S}$ rDNA exon sequences, which indicated that groups $\mathrm{B}$ and $\mathrm{C}$ were not the closest relatives (Fig. 3a). For instance, between groups $\mathrm{B}$ and C, 8 base substitutions were observed in the $18 \mathrm{~S}$ rDNA exons, but only 1 base substitution in the 26S rDNA domain D1/D2. The 1 base substitution in the 26S rDNA domain D1/D2 is within the range of conspecificity proposed by Kurtzman \& Robnett (1998). Nevertheless, DNA similarity values showed that group B is clearly a different species from group $\mathrm{C}$, and that it has intermediate similarity to group A (Table 2). Thus, it is suggested that the 18S rDNA exon tree corresponds to the result of DNA similarity (Fig. 3a) and that the 26S rDNA domain D1/D2 does not show the exact phylogenetic distance between groups B and $\mathrm{C}$ (Fig. 3b). This in turn suggests that species distinction using only 26S rDNA domain D1/D2 sequences might be mistaken.

\section{Estimation of the group I intron loss and insertion timing}

In the course of evolution, it is expected that these strains frequently lose or acquire the group I intron in the $18 \mathrm{~S}$ rDNA. The fact that no group I introns were 

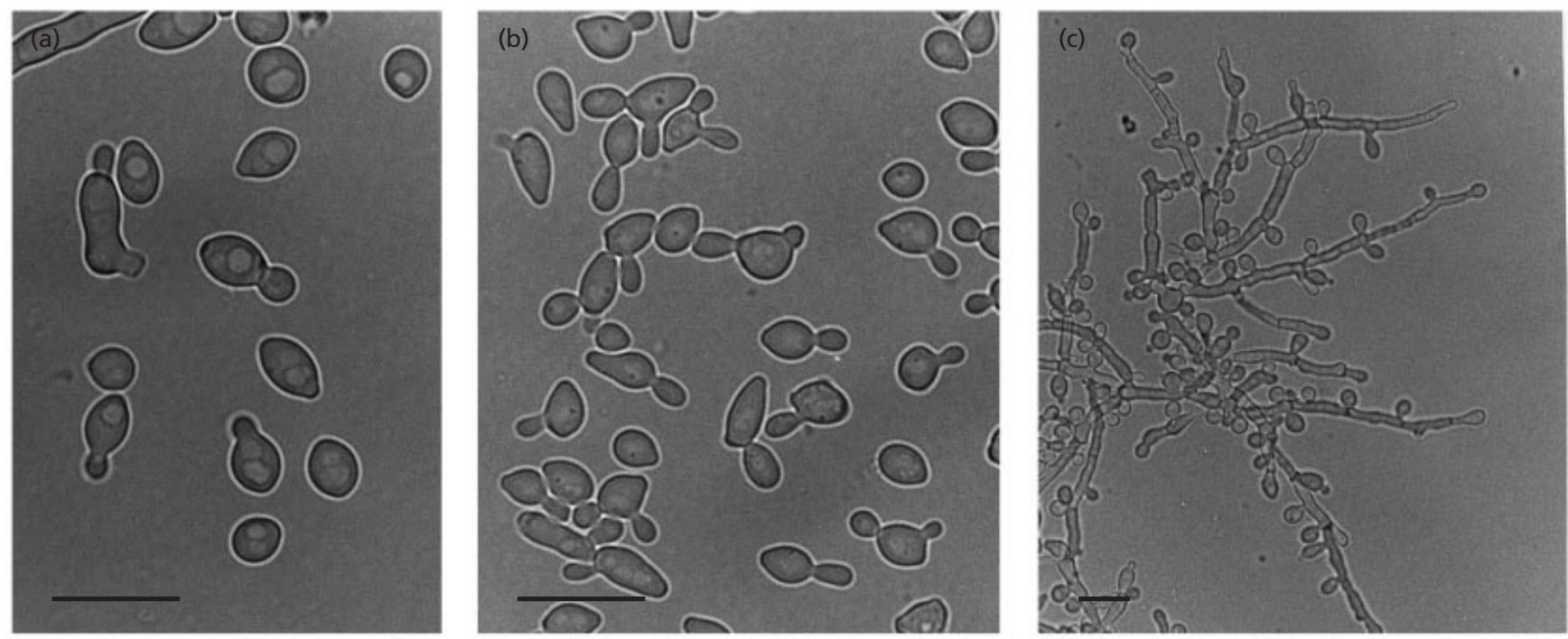

Fig. 4. Photomicrographs of Candida allociferrii in YM broth after 2 days at $24^{\circ} \mathrm{C}$. (a) Budding yeast cells, IFO $10194^{\mathrm{T}}$; (b) budding yeast cells, IFO 10193; (c) pseudohyphae, IFO 10194 ${ }^{\top}$. Bars, $10 \mu \mathrm{m}$.

found in the $18 \mathrm{~S}$ rDNA sequences of related species, except for that at position 1199 in Arxula terrestris (Ueda \& Mikata, 1999), suggests that the 18S rDNA of the common ancestor of the Stephanoascus ciferrii complex lacked group I introns. Because introns Sc1506-1 and Sc1506-2 must have been vertically transferred, it is suggested that the intronless ancestor of the Stephanoascus ciferrii complex first horizontally acquired Sc1506 as the prototype of Sc1506-1 and Sc1506-2. Because the group B strains with Sc1506-1 are more closely related to intronless group A than to group C with Sc1506-2 (Fig. 3a), it can be proposed that the ancestor of group A subsequently lost Sc1506 and that the ancestor of group $\mathrm{C}$ acquired the prototype of Sc943.

\section{Classification}

DNA similarity values demonstrated that group B strains, including the isotype strains of Stephanoascus ciferrii and the type strains of Candida ciferrii and Sporothrix catenata, are conspecific. Therefore, it was confirmed that group B strains correspond to Stephanoascus ciferrii and that Candida ciferrii and Sporothrix catenata are synonyms of Stephanoascus ciferrii. On the other hand, the single member of group C, IFO $10918^{\mathrm{T}}$, which corresponds to the type strain of Candida mucifera, was shown to be independent of the other tested strains by its low DNA similarity values. Thus, Candida mucifera should be regarded as an independent species from Stephanoascus ciferrii. The finding of intermediate DNA similarity values between groups A and B and a close relationship between them on the basis of $18 \mathrm{~S}$ rDNA exon phylogenetic analysis indicates that these groups have speciated recently and that group A might be a new Stephanoascus species. However, since group A strains could not form asci by themselves in this study, they are described as a new species for which the name Candida allociferrii sp. nov. is proposed.

\section{Latin diagnosis of Candida allociferrii sp. nov.}

In medio liquido $\mathrm{YM}$ post dies 2 ad $24{ }^{\circ} \mathrm{C}$, cellulae globosae vel elongatae $(1.7-4.5 \times 2.9-9.4 \mu \mathrm{m})$, cellulae singulae aut binae, per gemmationem multilateralem reproducentes. Post unum mensem sedimentum formatur. Pseudohyphae formatur. In agaro YM post unum mensem ad $24{ }^{\circ} \mathrm{C}$, coloniae alba vel cremea, farinose aut rugosa. Fermentatio nulla. Glucosum, galactosum, L-sorbosum, maltosum, sucrosum, cellobiosum, trehalosum, melibiosum, raffinosum, inulinum (lente), amylum solubile, D-xylosum, L-arabinosum, Darabinosum, D-ribosum, L-rhamnosum, ethanolum, glycerolum, erythritolum, ribitolum, galactitolum, D-mannitolum, D-glucitolum, methyl- $\alpha$-D-glucosidum, salicinum, acidum DL-lacticum, acidum succinicum, D-gluconatum, arbutinum et inositolum assimilantur, at non lactosum, melezitosum, glucono-1,5-lactonum nec acidum citricum. Ethylaminum assimilantur, at non kalium nitricum. Ad crescentiam vitaminae externae necessariae sunt. Augmentum in $37^{\circ} \mathrm{C}$. Typus stirps IFO $10194^{\mathrm{T}}$ (= CBS $5166^{\mathrm{T}}$ ) isolatus ex Homo sapiens, conservatur in collectionibus culturarum quas Institute for Fermentation, Osaka (IFO), Japonia.

\section{Description of Candida allociferrii sp. nov.}

Candida allociferrii (al.lo.ci.fer'ri.i. Gr. pron. allo another; L. gen. masc. n. ciferrii of Ciferrii; N.L. gen. masc. n. allociferrii another ciferrii, different but relating to Stephanoascus ciferrii).

After 2 days growth in YM medium at $24^{\circ} \mathrm{C}$, the yeast cells are ovoid or elongate $(1.7-4.5 \times 2.9-9.4 \mu \mathrm{m})$ and 
occur singly or in pairs (Fig. 4a, b). A sediment is present. Budding is multilateral. Pseudohyphae are formed (Fig. 4c). After 1 month growth on YM agar medium at $24{ }^{\circ} \mathrm{C}$, colonies are white to slightly cream with a mycelial surface, raised and wrinkled. Pseudohyphae grow from the reverse of the colony into the agar and from the margin of the colony to outside on the surface of agar. Ascospores were not detected in cultures of the three known strains of Candida allociferrii, nor in mixtures of the three, when grown on YM or corn meal agar at $24^{\circ} \mathrm{C}$ Candida allociferrii is closely related to Stephanoascus ciferrii and Candida mucifera; for this reason the Candida allociferrii type strain IFO $10194^{\mathrm{T}}\left(=\right.$ CBS $\left.5166^{\mathrm{T}}\right)$ mated with some strains of these two species (Table 3). Fermentation is negative. Glucose, galactose, L-sorbose, maltose, sucrose, cellobiose, trehalose, melibiose, raffinose, inulin (weak), soluble starch, D-xylose, L-arabinose, D-arabinose, D-ribose, L-rhamnose, ethanol, glycerol, erythritol, ribitol, galactitol, D-mannitol, D-glucitol, methyl- $\alpha$-D-glucoside, salicin, DL-lactic acid, succinic acid, D-gluconate, arbutin and inositol are assimilated, but not lactose, melezitose, D-glucono-1,5-lactone or citric acid. Ethylamine is assimilated as sole nitrogen source, but not potassium nitrate. Growth in vitaminfree medium is negative. Growth at $37^{\circ} \mathrm{C}$ is positive. Source of cultures: IFO 10193 and IFO $10194^{\mathrm{T}}$ were received from the Centraalbureau voor Schimmelcultures (CBS), Delft, The Netherlands, as Stephanoascus ciferrii (Smith et al., 1976) and had been isolated from a wooden pole in a cow shed and presumed human, respectively; IFO 10913 was received from the Japan Collection of Microorganisms (JCM) as Stephanoascus ciferrii isolated from pickled embric myrabolan in Thailand (Suzuki et al., 1987). Cultures of the type strain IFO $10194^{\mathrm{T}}\left(=\mathrm{CBS} 5166^{\mathrm{T}}\right)$ have been deposited in the culture collection of the Institute for Fermentation, Osaka (IFO), Japan.

\section{ACKNOWLEDGEMENTS}

We thank Professor Dr Hans G. Trüper, Institut für Mikrobiologie \& Biotechnologie, Universität Bonn, for help with the Latin name.

\section{REFERENCES}

Altschul, S. F., Gish, W., Miller, W., Myers, E. W. \& Lipman, D. J. (1990). Basic local alignment search tool. J Mol Biol 215, 403-410.

Bhattacharya, D., Friedl, T. \& Damberger, S. (1996). Nuclearencoded rDNA group I introns: Origin and phylogenetic relationships of insertion site lineages in the green algae. Mol Biol Evol 13, 978-989.

Cech, T. R. (1988). Conserved sequences and structures of group I introns: building an active site for RNA catalysis - a review. Gene 73, 259-271.

Cech, T. R., Damberger, S. H. \& Gutell, R. R. (1994). Representation of the secondary and tertiary structure of group I introns. Struct Biol $\mathbf{1}$, 273-280.

Davies, R. W., Waring, R. B., Ray, J. A., Brown, T. A. \& Scazzocchio, C. (1982). Making ends meet: a model for RNA splicing in fungal mitochondria. Nature 300, 719-724. de Hoog, G. S. \& Constantinescu, O. (1981). A new species of Sporothrix from calf skin. Antonie Leeuwnhoek 47, 367-370.

De Wachter, R., Neefs, J.-M., Goris, A. \& Van de Peer, Y. (1992). The gene coding for small ribosomal subunit RNA in the basidiomycete Ustilago maydis contains a group I intron. Nucleic Acids Res 20, 1251-1257.

Dobzhansky, T. (1976). Organismic and molecular aspects of species formation. In Molecular Evolution, pp. 95-105. Edited by F. J. Ayala. Sunderland, MA: Sinauer.

Ezaki, T., Hashimoto, Y., Takeuchi, N., Yamamoto, H., Liu, S.-L., Miura, H., Matsui, K. \& Yabuuchi, E. (1988). Simple genetic method to identify viridans group streptococci by colorimetric dot hybridization and fluorometric hybridization in microdilution wells. J Clin Microbiol 26, 1708-1713.

Ezaki, T., Hashimoto, Y. \& Yabuuchi, E. (1989). Fluorometric deoxyribonucleic acid-deoxyribonucleic acid hybridization in microdilution wells as an alternative to membrane filter hybridization in which radioisotopes are used to determine genetic relatedness among bacterial strains. Int J Syst Bacteriol 39, 224-229.

Felsenstein, J. (1985). Confidence limits on phylogenies: an approach using the bootstrap. Evolution 39, 783-791.

Gargas, A., DePriest, P. T. \& Taylor, J. W. (1995). Positions of multiple insertions in SSU rDNA of lichen-forming fungi. Mol Biol Evol 12, 208-218.

Gutell, R. R. (1993). Collection of small subunit (16S and 16S-like) ribosomal RNA structures. Nucleic Acids Res 21, 3051-3054.

Hibbett, D. S. (1996). Phylogenetic evidence for horizontal transmission of group I introns in the nuclear ribosomal DNA of mushroom-forming fungi. Mol Biol Evol 13, 903-917.

Holm, C., Meeks-Wagner, D. W., Fangman, W. L. \& Botstein, D. (1986). A rapid, efficient method for isolating DNA from yeast. Gene 42, 169-173.

Kaneko, Y. \& Banno, I. (1991). Re-examination of Saccharomyces bayanus strains by DNA-DNA hybridization and electrophoretic karyotyping. Inst Ferment Osaka Res Commun 15, 30-41.

Kimura, M. (1980). A simple method for estimating evolutionary rates of base substitutions through comparative studies of nucleotide sequences. J Mol Evol 16, 111-120.

Kocková-Kratochvílová, A. \& Sláviková, E. (1988). Candida mucifera n. sp. J Basic Microbiol 28, 613-618.

Kreger-van Rij, N. J. W. (1965). Candida ciferrii, a new yeast species. Mycopathol Mycol Appl 26, 49-52.

Kuhsel, M. G., Strickland, R. \& Palmer, J. D. (1990). An ancient group I intron shared by eubacteria and chloroplasts. Science 250, $1570-1573$

Kurtzman, C. P. (1987). Prediction of biological relatedness among yeasts from comparisons of nuclear DNA complementarity. Stud Mycol 30, 459-468.

Kurtzman, C. P. \& Phaff, H. J. (1987). Molecular taxonomy. In The Yeasts, vol. I, 2nd edn, pp. 63-94. Edited by A. H. Rose \& J. S. Harrison. London: Academic Press.

Kurtzman, C. P. \& Robnett, C. J. (1997). Identification of clinically important ascomycetous yeasts based on nucleotide divergence in the $5^{\prime}$ end of the large-subunit (26S) ribosomal DNA gene. J Clin Microbiol 35, 1216-1223.

Kurtzman, C. P. \& Robnett, C. J. (1998). Identification and phylogeny of ascomycetous yeasts from analysis of nuclear large subunit (26S) ribosomal DNA partial sequences. Antonie Leeuwenhoek 73, 331-371.

Lindegren, C. C. \& Lindegren, G. (1949). Unusual gene-controlled combinations of carbohydrate fermentations in yeast hybrids. Proc Natl Acad Sci U S A 35, 23-27.

Liu, Y. \& Leibowitz, M. J. (1993). Variation and in vitro splicing of group I introns in rRNA genes of Pneumocystis carinii. Nucleic Acids Res 21, 2415-2421.

McCullough, M. J., Clemons, K. V. \& Stevens, D. A. (1999). Molecular and phenotypic characterization of genotypic Candida albicans 
subgroups and comparison with Candida dubliniensis and Candida stellatoidea. J Clin Microbiol 37, 417-421.

Michel, F. \& Westhof, E. (1990). Modelling of the three-dimensional architecture of group I catalytic introns based on comparative sequence analysis. J Mol Biol 216, 585-610.

Nishida, H. \& Sugiyama, J. (1995). A common group I intron between a plant parasitic fungus and its host. Mol Biol Evol 12, 883-886.

Reinhold-Hurek, B. \& Shub, D. A. (1992). Self-splicing introns in tRNA genes of widely divergent bacteria. Nature 357, 173-176.

Saiki, R. K., Gelfand, D. H., Stoffel, S., Scharf, S. J., Higuchi, R., Horn, G. T., Mullis, K. B. \& Erlich, H. A. (1988). Primer-directed enzymatic amplification of DNA with a thermostable DNA polymerase. Science 239, 487-491.

Saitou, N. \& Nei, M. (1987). The neighbor-joining method: a new method for reconstructing phylogenetic trees. Mol Biol Evol 4, 406-425.

Shub, D. A., Gott, J. M., Xu, M. Q., Lang, B. F., Michel, F., Tomaschewski, J., Pedersen-Lane, J. \& Belfort, M. (1988). Structural conservation among three homologous introns of bacteriophase T4 and the group I introns of eukaryotes. Proc Natl Acad Sci U S A 85, $1151-1155$

Smith, M. Th. \& de Hoog, G. S. (1998). Stephanoascus M. Th. Smith, van der Walt \& E. Johannsen. In The Yeasts, a Taxonomic Study, 4th edn, pp. 400-403. Edited by C. P. Kurtzman \& J. W. Fell. Amsterdam: Elsevier.

Smith, M. Th., van der Walt, J. P. \& Johannsen, E. (1976). The genus Stephanoascus gen. nov. (Ascoideaceae). Antonie Leeuwenhoek 42, 119-127.

Sogin, M. L. \& Edman, J. C. (1989). A self-splicing intron in the small subunit rRNA gene of Pneumocystis carinii. Nucleic Acids Res 17, 5349-5359.

Suzuki, M., Nakase, T., Daengsubha, W., Chaowsangket, M., Suyanandana, P. \& Komagata, K. (1987). Identification of yeasts isolated from fermented foods and related materials in Thailand. J Gen Appl Microbiol 33, 205-220.
Takashima, M., Suh, S.-O. \& Nakase, T. (1996). Group I introns found in nuclear small subunit ribosomal RNA genes of the ballistoconidiogenous anamorphic yeasts Bensingtonia cliata and Bensingtonia yamatoana. J Gen Appl Microbiol 42, 189-200.

Ueda, K. \& Mikata, K. (1999). A group I intron in the nuclear $18 \mathrm{~S}$ rRNA gene of the yeast-like fungus, Arxula terrestris. Inst Ferment Osaka Res Commun 19, 15-21.

Ueda-Nishimura, K. \& Mikata, K. (1999). A new yeast genus Tetrapisispora gen. nov.: Tetrapisispora iriomotenesis sp. nov., Tetrapisispora nanseiensis sp. nov. and Tetrapisispora arboricola sp. nov., from the Nansei Islands, and reclassification of Kluyveromyces phaffii (van der Walt) van der Walt as Tetrapisispora phaffii comb. nov. Int $J$ Syst Bacteriol 49, 1915-1924.

Wilcox, L. W., Lewis, L. A., Fuerst, P. A. \& Floyd, G. L. (1992). Group I introns within the nuclear-encoded small-subunit rRNA gene of three green algae. Mol Biol Evol 9, 1103-1118.

Winge, Ö. \& Roberts, C. (1949). Inheritance of enzymatic characters in yeast, and the phenomenon of long-term adaptation. C R Trav Lab Carlsberg 24, 263-315.

Xu, M. Q., Kathe, S. D., Goodrich-Blair, H., Nierwicki-Bauer, S. A. \& Shub, D. A. (1990). Bacterial origin of a chloroplast intron: conserved self-splicing group I introns in cyanobacteria. Science $\mathbf{2 5 0}$, 1566-1570.

Yamada, T., Tamura, K., Aimi, T. \& Songsri, P. (1994). Self-splicing group I introns in eukaryotic viruses. Nucleic Acids Res 22, 2532-2537.

Yamada, Y. \& Nogawa, C. (1990). The molecular phylogeny of the ascomycetous anamorphic yeast genus Arxula van der Walt, Smith et Yamada, based on the partial sequences of $18 \mathrm{~S}$ and $26 \mathrm{~S}$ ribosomal ribonucleic acids. J Gen Appl Microbiol 36, 425-434.

Yarrow, D. (1998). Methods for the isolation, maintenance and identification of yeasts. In The Yeasts, a Taxonomic Study, 4th edn, pp. 77-100. Edited by C. P. Kurtzman \& J. W. Fell. Amsterdam: Elsevier. 